\title{
"O punk da integração", o consenso na cena rock do Alto do José do Pinho
}

\author{
Lydia Barros ${ }^{1}$ \\ UFPE
}

\begin{abstract}
Resumo: $O$ presente artigo analisa a reelaboração das estratégias discursivas das bandas de rock do Alto José do Pinho, na periferia do Grande Recife, a partir da representação desse movimento musical pelos meios de comunicação massivos. Focaliza esta produção subcultural em sua interface com a indústria hegemônica, cristalizando as singularidades dos grupos ali baseados e o esforço empreendido pelas bandas visando à conquista de visibilidade e inserção sociocultural. Nesse sentido, ressalta o distanciamento do punk rock ali produzido da matriz antinormativa do movimento, a fim de estabelecer uma comunicação distintiva com o mercado cultural institucional.
\end{abstract}

Palavras-chave: subcultura, representação, mercado.

\begin{abstract}
The current paper analyses the re-thinking of the discourse strategies of rock bands from Alto José do Pinho, a district in the outskirts of the Greater Recife, taking as a starting point the social representation of this musical movement made by the mass media. It focus on the interface between this sub-cultural production and the hegemonic industry by crystallizing not only the singularities of the groups therein based as well as the effort made by the bands whose aim has been to conquer visibility and socio-cultural insertion. In this sense, it enhances the distance between the punk rock produced there and the anti-normative matrix of the movement in order to establish a distinct communication with the institutional cultural market.
\end{abstract}

Keywords: subculture; representation, market.

Resumen: El presente artículo haz una análisis de la relaboración de las estretegías discursivas de los conjuntos musicales de rock del Alto José do Pinho, suburbio de la Grand Recife - después de la difusión deste género musical en los medios de comunicación de massas. El estudio enfoca la produción subcultural en suya interface con la industria hegemonica, consolidando su singularidad - y el esfuerzo empezado por los conjuntos musicales, en una búsqueda por visibilidad y inserción sociocultural. En este sentido, señala el distanciamiento entre el punk rock hecho en Alto José do Pinho y la matriz antinormativa del movimiento original, con objeto de consolidar una comunicación distinta del mercado cultural institucional.

Palabras-clave: subcultura, representaciones, mercado.

1 Jornalista, Doutoranda em Comunicação pela UFPE 


\section{Roqueiros do bem}

A abolição de antigas categorias discursivas na dinâmica cultural do contemporâneo embaralha as identidades subculturais e põe em xeque representações consagradas no campo das subculturas. A imprecisão do termo é evidenciada quando colocados em questão antigos elementos de diferenciação desses grupos, como a manutenção de territorialidades, a auto-segregação, as narrativas sociais e a negação ao consumo e ao establishment. No campo da música popular, as identidades subculturais estão ainda mais fragmentadas, uma vez que o gosto musical é eclético e está mais ligado a afiliações múltiplas do que às identidades (Gelder, 1997), considerando o fato de a música estar inserida nos contextos da indústria e, como tal, operar com essa perspectiva. A essência múltipla e contraditória da música produzida nessas conformações sociais ora reafirma a existência de redes de afiliação e socialidades ${ }^{2}$ subculturais, em sua tradição anticomercial que reivindica autenticidade e busca legitimação 'nas ruas'; ora ratifica o seu valor de mercado na dinâmica das indústrias culturais, segundo a lógica capitalista que dissemina e coloniza a cultura musical. Tal ambivalência é materializada em cenas musicais ${ }^{3}$ como a do Alto José do Pinho, bairro situado na periferia da Região Metropolitana do Recife, onde bandas alternativas conseguiram inserir a comunidade na cartografia da urbe, conquistando visibilidade social e status cultural até então inéditos para o bairro.

Analisando esse circuito alternativo de produção cultural em sua interface com a indústria hegemônica, é possível perceber a reelaboração das estratégias discursivas das bandas, visando tanto à legitimação de sua produção cultural quanto a construção da sua cidadania. Identificadas com a diversidade musical propagada pelo movimento Manguebeat ${ }^{4}$ no início da década de 90 , as bandas (capitaneadas

\footnotetext{
2 Trabalha-se aqui com a noção de socialidade defendida por Maffesoli, em oposição à sociabilidade, sendo a primeira usada para definir as relações pontuais, superficiais e afetivas, e a segunda empregada na definição de relações estáveis, duradouras, familiares 3 Cena musical neste texto remete a coexistência de práticas musicais que interagem através de processos de diferenciação, nos termos defendidos por Straw (1991) e desenvolvidos por autores como Freire Filho (Freire Filho e Janotti Júnior, 2006).

4 Movimento baseado na estética da mistura de elementos das culturas regional e nacional, com informações globais situadas no universo pop, que permitiu a construção de uma identidade cultural genuína para Pernambuco, e que teve como principais porta-vozes as bandas Chico Science \& Nação Zumbi e Mundo Livre S/A.
} 
pelo grupo de punk rock hardcore Devotos do Ódio - o ódio do nome viria a ser suprimido, como veremos adiante), dão visibilidade ao bairro, reivindicam direitos, e denunciam desigualdades, atrelando sua produção às demandas sociais da comunidade; ao mesmo tempo em que se deixam orientar pelas regras do mercado, buscando a melhor forma de ingressar no "ciclo de inclusão" dessa indústria (Connor, 2000).

O abrandamento do punk rock produzido naquele bairro aponta para o que pode ser descrito, alegoricamente, como um punk da integração, um processo de ressignificação da música e da atitude punks, a partir da reapropriação de sua matriz global. Bom mocismo que encontra referências tanto na demanda por reconhecimento e cordialidade 5 que estão na base da formação cultural brasileira; quanto na dimensão mercadológica das subculturas - jovens socialmente estigmatizados e excluídos, cuja visibilidade alimenta as engrenagens do capitalismo globalizado e a agenda do mercado (Herschmann, 2000).

Observa-se que a rebeldia juvenil se expressa e ganha notoriedade nos seus vários points, articulando, como ressalta Sposito, exclusão e integração. Essa articulação está marcada 'pela inserção deste jovem no mundo do consumo, da produção de imagens, símbolos e mídias' e pela impossibilidade de consumirem grande parte dos produtos postos em circulação. A exclusão e a rebeldia juvenil invadem o palco da cidade, produzem enredos diversificados, nos quais a pluralidade e a diversidade da 'visitação urbana' se articulam dentro de um mesmo mote: o direito de ser reconhecido como cidadão e consumidor da cidade. (Diógenes, 1997, p: 123)

Deve-se ressaltar que as representações constituídas pelos meios de comunicação de massa do punk rock do Alto José do Pinho terminaram por moldar as interrelações entre os moradores do lugar, reforçando uma espécie de enquadramento das bandas no espelho midiático, que resultou, em um primeiro momento, na legitimação desta cena alternativa em seu território original - onde antes não encontrava acolhida. Nesse processo de ressignificação do punk rock, os artistas do Alto ratificam a identidade proletária do movimento punk, mas, principalmente, reivindicam a atualização da expressão punk: abandonam o niilismo e a fúria marcados historicamente neste movimento e assumem o engajamento político e

5 Sérgio Buarque de Holanda argumenta que tanto o personalismo quanto o cordialismo estão relacionados às afetividades originadas em uma cultura patriarcalista e escravocata. 
social, através de uma retórica que chamam de construtiva e de atitudes que têm por objetivo a diluição da má reputação do movimento.

Há uma inegável afinidade ideológica entre o bom mocismo do punk rock do Alto José do Pinho e as muitas vertentes de engajamento social e político do movimento punk atual (O’Hara, 2005), inclusive, com subculturas como o Straight Edge, que se afasta deliberadamente das drogas e do álcool (Haenfler, 2004; Williams, 2006), posicionamento este também assumido pelos grupos da comunidade. Aqui, o punk não precisa travar nenhum tipo de embate com os meios de comunicação massivos, freqüentemente dispostos a negativizar as atuações desses grupos, uma vez que os músicos do Alto José do Pinho foram beneficiados pela "lógica da novidade" (Herschmann e Kischinhevsky, 2006) que então impulsionava o Manguebeat na mídia. Abre-se espaço a uma mediação entre o espaço social no qual estes atores estão inseridos e a sociedade, não tanto por interesse em sua dimensão sociocultural, mas em um esforço de apreensão do Outro pacificado. Em contrapartida, as estratégias discursivas desses punks deixam de lado o desejo de ruptura e de destruição dos adversários de praxe: os espaços normativos, o poder, o sistema, a polícia...

Observa-se no Alto José do Pinho uma necessidade latente de romper as fronteiras da periferia e fazer circular a sua mercadoria para muito além dos subterrâneos subculturais, ainda que, para isso, tenham que ser estabelecidos valores consensuais. Este posicionamento teve como desdobramento, entre outros, o afastamento dos punks do bairro do movimento punk recifense, que acusava as bandas daquele subúrbio de rendidas, distribuía panfletos insuflando os punks da cidade contra o movimento do Alto e provocava briga sempre que os grupos se encontravam ${ }^{6}$.

Nessa perspectiva, também se percebe entre os grupos, sobretudo o Devotos, uma preocupação mercadológica que pode ser ilustrada pela fala de Cannibal, líder e guitarrista da banda, recordando o começo da carreira, quando o seu público ainda era formado basicamente por punks dos subúrbios do Recife, que costumavam

\footnotetext{
${ }^{6}$ Além dos encontros semanais a céu aberto, nos quais se discutia política e se deliberava sobre iniciativas como fazer pichações no centro da cidade, os punks recifenses se encontravam em festas e shows do circuito periférico, onde, na maioria das vezes, se davam os embates.
} 
quebrar mesas, cadeiras e instalações hidráulicas das casas onde a banda se apresentava: "Eu não achava legal, a gente batalhava tanto e, de repente, não rolava mais shows, os espaços iam diminuindo" (entrevista em 12.02.05). O desejo de diferenciação levou o grupo à decisão de retirar o "ódio" do nome com o qual originalmente se lançou, ao posicionamento anti-drogas e a aproximação com entidades sociais do bairro.

\section{Negociações cotidianas}

Assim como as reapropriações do funk e do hip hop, com sua exposição midiática, adquiriram novos contornos sociais e políticos, o punk produzido no Alto José do Pinho, a partir da sua midiatização, resulta na "pacificação" da atitude roqueira dos jovens da comunidade, espaço de significação no qual a idéia de resistência é substituída pelo desejo de emancipação sociocultural. Não há, a julgar pelos depoimentos colhidos em campo, um alinhamento consciente das bandas do Alto José do Pinho com a nova matriz do punk rock mundializado, aquela da ação política positiva do underground (FREIRE FILHO, 2006). Integrantes das bandas do bairro apenas reivindicam palco, trabalham para abrir espaço, e alimentam a esperança de mobilidade social através de sua arte - a redenção por um trabalho que, apesar das formas de circulação e consumo, acreditam distante dos padrões normativos.

Percebe-se aqui uma tensão entre o discurso social das bandas e a possibilidade de neutralização dos conflitos de classe, através de estratégias mercadológicas (Rosini, 2006). Os músicos ratificam a distância entre a ideologia punk fechada em guetos e a atitude das bandas daquela periferia, que utilizam o protesto com vistas à transformação social. É na retórica pacifista que eles encontram a senha de sua legitimação pela comunidade e a possibilidade de entrar no circuito institucional de produção e consumo culturais. É relevante observar essa aparente contradição, inclusive, no que diz respeito à relação do grupo Devotos com os meios de comunicação massivos:

A gente não tem preconceito com a mídia. Fizemos programas de televisão que a galera não queria fazer; quando diziam que não era pra gente tocar para aquelas pessoas, eu dizia que era para elas que a gente queria tocar, porque assim estaríamos falando para pessoas que tinham preconceito com o subúrbio, que nunca tinham pisado 
em uma periferia (...) As primeiras bandas que fizeram o rap crescer no Brasil, por exemplo, têm um preconceito muito grande com a mídia. Nós não temos. (Cannibal, em 12.02.05)

Observa-se que, embora o músico manifeste o desejo de diferenciação da banda em relação ao hip hop, o punk produzido naquela comunidade se aproxima em muitos momentos do rap, uma vez que é a música, na condição de mercadoria, que lhes garante, além da partilha de uma identidade coletiva, a assimilação dos seus bens culturais pelo mercado. Lembre-se aqui Herschmann (1997), quando afirma que os estilos híbridos constituídos por rappers e funkeiros ocupam ao mesmo tempo uma posição periférica e central na cultura contemporânea: são associados às gangues e ao crime organizado, mas despertam interesse crescente em torno da sua produção cultural. Contra a invisibilidade a que estão condenados, explica o autor, surgem novos espaços de significação a partir dos quais esses sujeitos conquistam o direito à voz.

Para contornar as resistências à cena musical alternativa em seu território original, os jovens músicos do Alto José do Pinho defendem a diversidade cultural do bairro e selam alianças comunitárias, para além das afiliações identitárias, optando por relações de cordialidade no interior daquela periferia. Essa singularidade distancia esta cena de outros movimentos juvenis como o heavy metal, e - nessa perspectiva - até mesmo, conceitualmente, do hip hop, que, como apontam diversos pesquisadores, opta pelo confronto, distante do consenso solene da cultura oficial (Yúdice, 1997).

Não que o punk do Alto José do Pinho ratifique a idéia de harmonia social, projetada pela camuflagem estética da democracia racial - o mito de origem da sociedade brasileira propagada por autores como Gilberto Freyre -, ou que ignore o poder de fogo da retórica da diferença cultural, através da qual negocia e fortalece o calibre de sua inserção no mercado. Mas a organicidade da vida cotidiana no Alto, na qual a busca por legitimação passa pela valorização dos sujeitos coletivos, reforçando a dinâmica interconstituinte entre indivíduo e sociedade (Maturana, 2002), carrega fortes componentes de emotividade e da demanda por reconhecimento.

A intencionalidade dessa cena cultural é de transformação do punk em um ambiente de solidariedade social. Retire-se aqui o caráter negativo da crítica ao 
abrandamento da natureza do homem brasileiro, segundo Yúdice (1977), um mito produzido pelas elites para lhes aplacar o temor da diferença; para ressaltar que, embora o punk do Alto José do Pinho testemunhe uma realidade de exclusão social e reivindique o direito à voz de uma periferia, a lógica que lhe move é a do consenso, interno e externo - vide sua relação com os mercados institucionais e os espaços normativos.

Pesquisando as linguagens da violência, Micael Herschmann, Carlos Alberto M. Pereira, Elizabeth Rondelli e Karl Schollhammer (2000) afirmam que a representação da violência no imaginário social hegemônico provoca um mal-estar em grande parte da população exatamente pela ilusão criada, ao longo dos anos, de um Brasil pacífico e ordeiro - o país cordial a que se referia Buarque de Holanda. Ainda que defendam a importância da violência na dinâmica social e suas potencialidades desestruturadoras e fundadoras, esses autores reconhecem que, ao cristalizar o fosso social brasileiro, as expressões culturais da periferia acabam submetidas à lógica do preconceito e da discriminação. É visando uma identidade distintiva que lhes permita ocupar uma "posição no mundo", que jovens funkeiros, segundo Herschmann, acabam se vendo forçados a se adequar aos padrões de noticiabilidade dos mass media. Plasticidade que pode ser observada entre as bandas punks do Alto José do Pinho, que se esforçam em tornar real a sua representação midiática, a partir da qual reivindicam cidadania e satisfazem as demandas da comunidade.

A atitude punk daquela periferia parece mais sintonizada com a noção de rebeldia da geração pós-moderna defendida por Glória Diógenes, afirmando, embasada em Agnes Heller, que esta está fadada a contra nada se rebelar, podendo ocorrer apenas alguns microespaços de revolta, "onde todo tipo de rebelião é permitida, sem que nenhuma causa específica tenha de ser claramente acordada e revelada" (Diógenes, 1997, p: 117). Fenômeno que encontra ressonância na própria ambivalência da marginalidade no contemporâneo, como aponta Connor, referindose à circulação de formas culturais marginais visíveis, eficazes e muitas vezes lucrativas: “(...) a marginalidade e a centralidade deram um salto mortal que produziu uma inversão exata, pois o pretenso marginal torna-se o representativo 'porta-voz' da sociedade” (Connor, 2000, p: 153). 


\section{Quem é quem}

A relação da banda Devotos com o mercado se diferencia substancialmente dos demais grupos do bairro, o que pode ser compreendido tanto sob a ótica da sua profissionalização ${ }^{7}$, como da sua apropriação pelas indústrias culturais, perdendo o seu caráter de resistência - o que o presente artigo não se propõe a analisar. Mais apropriado, neste caso, é conhecer as motivações por trás das opções estéticas e ideológicas dos grupos desta cena para entender de que maneira a construção de uma realidade midiática (retro) alimentou essa produção artística e as socialidades do bairro.

Tome-se o exemplo da banda Matalanamão, formada em 1993, no entusiasmo da emergência do movimento musical do bairro, baseada na matriz anárquica do movimento punk. A idéia era deixar os temas "sérios" com o Devotos e abrir frente para o humor. Os integrantes animavam festinhas com paródias de composições de bandas recifenses, crônicas irreverentes sobre assuntos que estivessem na mídia e, principalmente, cantando com sarcasmo as aventuras afetivas e sexuais dos jovens das periferias. A banda conquistou fama no circuito underground da cidade, participando de shows e eventos ligados à cena mangue, e virou uma espécie de coringa do movimento musical do Alto José do Pinho, quando Devotos iniciou sua rotina de excursões pelo país. Experimentou, assim, uma fase de agenda lotada com shows e apresentações especiais nos palcos da Grande Recife. Embora alimentassem o sonho de poder "viver somente de música”, os integrantes do grupo declaram que a circulação de sua produção musical nos canais culturais institucionais nunca foi pretensão do grupo.

Deve-se ter em mente, contudo, que apesar do processo de fruição da música por eles produzida passar por canais subculturais, engendrando sentidos coletivos da periferia para o centro, a sua identificação com a lógica capitalista de mercado não pode ser excluída. A visibilidade da banda Matalanamão, e das suas 'irmãs' III Mundo e Armas da Verdade, cristaliza o paradoxo entre a existência do punk

\footnotetext{
7 A banda teve como empresário o produtor Paulo André Pires (Abril Pro Rock) de 1994 a 1996; esteve sob a retaguarda logística da BMG/Ariola de 1997 a 1998, quando lançou seu primeiro disco pelo selo Plug; produziu seu segundo CD na Rockets, de Dado Villa Lobos; e gravou o terceiro CD em estúdio próprio com produção independente. Possui página na Internet, gravou três videoclipes, tem um DVD no mercado e está produzindo o segundo.
} 
periférico recifense, onde atuam dezenas de grupos que revitalizam um circuito cultural subterrâneo ignorado pelos media, e a imagem publicizada pelos meios de comunicação, na qual aparecem como protagonistas de uma cena cultural vigorosa e homogênea - detentoras, portanto, do capital subcultural de que trata Thornton (1995) -, produto identificado com as demandas do mercado. A partir dessa existência na esfera pública, elas abrem canais de circulação cultural e comunicação com a sociedade. Assim, também é possível afirmar a ambição desses grupos em reproduzir o ideal midiático de transformação social através de sua expressão cultural, e isso vale mesmo para os grupos que assumem a sua despretensão profissional e mantém postura semelhante ao início do movimento nos anos 90, quando, então, formar bandas e fazer shows era uma brincadeira de garotos.

Talvez fosse possível apresentar como exceção a essa hipótese a trajetória do Armas da Verdade, formado em 1997 por adolescentes da comunidade e jovens do bairro do Ipsep, em sua atitude de insubordinação à hierarquia do movimento. No entanto, os integrantes assumem o "oportunismo" da criação do grupo, numa época em que os jornais subiam o morro "para ver o que estava acontecendo", músicos de renome nacional visitavam o bairro interessados naquela cena em ebulição, e em que eles "procuravam algo com que se ocupar" (entrevista em 05.03.05). O desejo de produzir, colocar em circulação e consumir bens culturais está cristalizado na fala de cada um dos integrantes da banda, que, entretanto, preferem adotar posicionamento crítico em relação aos demais grupos da comunidade.

A aparente negação de adesão aos circuitos culturais institucionais, neste caso, é compatível com a atitude roqueira de rebeldia juvenil (todos à época com menos de 20 anos), a liberação da energia, da frustração e da fúria reprimidos, além do desejo de atenção característico da idade, que os faz posicionar-se como se nada mais importasse além do seu punk rock e da sua revolta. Nos termos defendidos por Helena Abramo, em sua investigação sobre os punks e darks no espetáculo urbano (1994), trata-se da dificuldade de se tornar adulto e fazer parte do modo de vida dominante. Mas é preciso ter em mente que o desejo de reconhecimento e visibilidade também atravessa o discurso da banda caçula do Alto para revelar toda a sua ambivalência. 
A reivindicada condição de marginalidade do Armas da Verdade, assim, não libera o seu valor de mercadoria, uma vez que o grupo está inserido em uma cena musical na qual os interesses de cada grupo - e isso inclui a afirmação de afiliações identitárias distintivas - são permanentemente tensionados e negociados. Novamente aqui, pode-se evocar a idéia de capital subcultural de Sarah Thornton (1995), que, ao ampliar o esquema teórico de Bourdieu, lança luz sobre as "subespécies" de capital que operam em domínios sociais menos privilegiados. Vale ressaltar a relevância atribuída pela autora aos media - tanto a mídia de massa quanto as chamadas micromídias - como importante fator de influência para a construção e circulação do capital subcultural, uma vez que a hierarquização da cena musical do Alto José do Pinho reflete o grau de ascendência de cada uma das bandas sobre a comunidade.

[A mídia não é apenas mais um bem simbólico ou uma marca de distinção (que é a maneira como Bourdieu descreve filmes e jornais em relação ao capital cultural), mas uma rede crucial para a definição e distribuição do conhecimento cultural. Em outras palavras, a diferença entre estar dentro ou fora da moda, com alto ou baixo capital cultural, está relacionada, de maneira complexa, aos níveis de cobertura, criação e exposição midiática] (Thornton, 2005: 187)

Debruçada sobre a cultura club, Thornton argumenta que os sujeitos investidos desse capital - DJs, estilistas, produtores, jornalistas especializados, no caso investigado pela autora; grupos do bairro e profissionais e fãs que se articulam em torno deles, na presente análise - articulam suas experiências pessoais e profissionais em função do status e do respeito acumulado, deliberadamente ou não, na intenção de convertê-lo em capital econômico. Assim, parece natural o esforço de manutenção das afiliações subculturais no bairro, demonstrado inclusive por grupos como o Armas da Verdade.

Há disputas visíveis tencionando as alianças forjadas na cena musical do Alto José do Pinho. Mas há uma intenção mercadológica para além das motivações pessoais e posicionamentos ideológicos dos seus agentes. Cannibal, espécie de portavoz do movimento musical do bairro, assume o discurso da profissionalização. A idéia, segundo ele, é a inserção no mercado fonográfico metropolitano e nacional. Para seus músicos do grupo, não há mais, se é que já houve, uma necessidade de "descer aos infernos, como único modo de estabelecer uma relação verdadeira com a sua condição e estar alerta para as questões do seu próprio tempo", que a socióloga 
Helena Abramo (1994) identifica na cultura punk. Para o grupo, o punk existe sem essa catarse estética e ideológica, e deve ser encarado como instrumento através do qual as minorias podem expressar suas reivindicações sociais e culturais.

\section{Considerações finais}

Pode-se afirmar que, assim como o hip hop reelabora suas estratégias discursivas para ganhar visibilidade, "romper os 'muros' e os signos do estigma territorial” (Diógenes, 1997, p:.41), o punk rock do Alto José do Pinho distancia-se da matriz violenta do punk para estabelecer uma comunicação distintiva com o mercado cultural institucional. Nesse sentido, sela alianças para dar visibilidade às demandas sociais da comunidade, moldando a sua rebeldia à lógica da ordenação social através da (re) apropriação e difusão de signos culturais. Assim, os punks daquela periferia preservam a contundência da retórica anti-sistema nas letras de suas canções, mas aspiram a carreiras musicais bem-sucedidas, que possam lhes garantir a manutenção do seu capital subcultural, além de uma estabilidade financeira mínima, ou, no caso da banda mais jovem, a produção e o consumo de um gênero musical no qual ele possa se reconhecer e a seu grupo.

"Sentimos que já é hora da batalha/ Raios e trovões esbravejam seu ódio sem piedade/ Somos a minoria, mas estamos preparados/ Eles são a maioria/ Mas a desunião os tornaram fracos/ Vamos lutar pra vencer/ Sem medo de falhar/ Unidos vamos viver/ Unidos vamos brilhar/ A batalha vai ser forte e sangrenta/ Não haverá lugar para os fracos/ Não queremos uma guerra armada/ Mas como já dissemos estamos preparados" (Devotos, Hora da Batalha, de disco homônimo, gravado no estúdio da banda, de 11/2002 a 02/2003)

A afirmação do Alto como espaço de produção simbólica remete aos estudos de Fausto Neto e Quiroga (2000) sobre a juventude pobre brasileira, no qual os autores percebem que os espaços de vida desses sujeitos não estão mais sendo ocultados, como o fizeram as antigas gerações de moradores de favelas e periferias. A positivação do pertencimento a um território, a partir do qual é constituída uma identidade cultural no imaginário coletivo da cidade, abre, nesse sentido, a brecha através da qual esses grupos expõem suas demandas por legitimidade e reconhecimento - de igualdade e de diferença - onde negociam acesso aos espaços normativos da vida social. 
Dessa forma, é possível afirmar que o fenômeno musical daquela periferia opera a sua inserção tanto no contexto da cultura de massa globalizada, ao ressignificar produtos e valores originados em um centro propagador; quanto na perspectiva do fechamento dessa partilha de sentidos, no campo social da comunidade, onde se estabelecem negociações "paroquiais" territorializadas. Assim, os grupos alternativos do bairro se apropriam do que lhes interessa, como fixação de identidade, através dos canais midiáticos, ou, dizendo de outra forma, através das produções de sentidos desterritorializadas, ao mesmo tempo em que reafirmam a importância do reconhecimento do território a partir do qual eles falam, para além do seu valor simbólico e identitário, mas na lógica de sua materialidade funcional.

\section{Bibliografia:}

ABRAMO, Helena Wendel. Cenas juvenis: punks e darks no cenário urbano. São Paulo: Scritta, 1994. ; BRANCO, Pedro Paulo Martoni (Org). Retratos da juventude brasileira - análise de uma pesquisa nacional. São Paulo: Fundação Perseu Abramo, 2004. ; FREITAS, Maria Virgínia de; SPOSITO, Marília Pontes (Org). Juventude em debate. $2^{\mathrm{a}}$ edição. São Paulo: Cortez, 2002.

BOURDIEU, Pierre. O poder simbólico. $6^{\text {a }}$ edição. Rio de Janeiro: Bertrand Brasil Ltda, 2003.

CONNOR, Steven. Cultura pós-moderna. Introdução às teorias do contemporâneo. $4^{\mathrm{a}}$ edição. São Paulo: Loyola, 2000.

CARMO, Paulo Sérgio do. Culturas da rebeldia - a juventude em questão. $2^{\text {a }}$ edição. São Paulo: Senac Editora, 2000.

DAMATTA, Roberto. A Casa \& a Rua. 6a edição. Rio de Janeiro: Rocco, 2000.

DIÓGENES, Glória. Cartografias da cultura da violência: gangues, galeras e o movimento hip hop. Fortaleza: Secretaria de Cultura e Desporto, 1998.

Rebeldia urbana: tramas de exclusão e violência juvenil. In Herschmann, Miacel (Org). Abalando os Anos 9o. Funk e hip hop. Rio de Janeiro: Rocco, 1997. 
Gangues e polícia: campos de enfrentamento e estratégias de diferenciação. In PEREIRA, Carlos Alberto M.; RONDELLI, Elizabeth; SCHOLLGAMMER, Karl E. et al. (Org). Linguagens da violência. Rio de Janeiro: Rocco, 2000.

FAUSTO NETO, Ana Maria Q.; QUIROGA, Consuelo. Juventude urbana pobre: manifestações públicas e leituras sociais. In PEREIRA, Carlos Alberto M. et al. Linguagens da violência. Rio de Janeiro: Rocco, 2000.

FREIRE FILHO, João. Jovens, espaço urbano e identidade: reflexões sobre o conceito de cena musical. In FREIRE FILHO, João; JANOTTI JÚNIOR, Jéder (orgs). Comunicação \& música popular massiva. Salvador: Editora da Universidade Federal da Bahia, 2006.

Repensando a resistência juvenil: música, política e a recriação do espaço público. In PRYSTHON, Ângela (Org). Imagens da cidade. Espaços urbanos na comunicação e cultura contemporânea. Porto Alegre: Editora Sulina, 2006.

GELDER, Ken. The Subcultures Reader. Inglaterra: Routledge, Taylor \& Francis Group, 2005

HAENFLER, Ross. Rethinking subcultural resistance - core values of the straight edge movement. In Journal of Contemporary Ethnography, vol. $33, \mathrm{n}^{\circ} 4,2004$.

HERSCHMANN, Micael (Org). Abalando os anos 90 - funk e o hip hop. Globalização, violência e estilo cultural. Rio de Janeiro: Rocco, 1997.

. As imagens das galeras funks na Imprensa. In:. PEREIRA, Carlos Alberto M. et al. Linguagens da violência Rio de Janeiro: Rocco, 2000, fs 11 X 22.

; KISCHINHEVSKY, Marcelo. A indústria da música brasileira hoje - riscos e oportunidades. In FREIRE FILHO, João e JANOTTI JÚNIOR, Jéder (orgs). Comunicação \& música popular massiva.. Salvador: Edufba, 2006.

HOLANDA, Sérgio Buarque de. Raízes do Brasil. $8^{\text {a }}$ edição. Volume I. Rio de Janeiro: José Olympio Editora, Coleção Documentos Brasileiros, 1975.

MATURAMA, Humberto. A ontologia da realidade. $3^{\text {a }}$ edição. MAGRO, Cristina; GRACIANO, Mirian: VAZ, Nelson (Org). Belo Horizonte: Editora UFMG, 2002.

MAFFESOLI, Michel. O Tempo das tribos. O declínio do individualismo nas sociedades de massa. 3. ed. Rio de Janeiro: Editora Forense Universitária, 2002.

MONTEIRO, Tiago José Lemos. Identidade, afeto e autenticidade: a (in)validade do discurso da ideologia do rock no cenário musical contemporâneo. In FREIRE FILHO, João e JANOTTI JÙNIOR, Jeder (orgs). Comunicação \& música popular massiva. Salvador: Edufba, 2006.

O'HARA, Criag. A filosofia do punk, mais do que barulho. São Paulo: Radical Livros, 2005. 
PEREIRA, Carlos Alberto M.; RONDELLI, Elizabeth; SCHOLLHAMMER, Karl; HERSCHMANN (Orgs). Linguagens da violência. Rio de Janeiro: Rocco, 2000.

RONSINI, Veneza Mayora. A Política de representação do hip hop e a lógica mercantil: consenso e dissenso. In: FREIRE FILHO, João e JANOTTI Júnior (orgs). Comunicação \& música popular massiva. Salvador: Edufba, 2006.

THORNTON, Sarah. The social logic of subcultural capital. In . GELDER, Ken. The subcultures reader. 3 ed. Londres e Nova York: Routlegde, 2005.

WILLIAMS, Patrick J. Authentic identities, Straight Edge subculture, music and Internet. In Journal of Contemporary Ethnography, vol 35, $\mathrm{n}^{\circ}$ 2, 2006.

YUDICE, George. A funkificação do Rio. In: HERSCHMANN, Micail (org). Abalando os anos 90: funk e hip hop. globalização, violência e estilo cultural. Rio de Janeiro: Rocco, 1997. Rio de Janeiro: Rocco, 1997. 